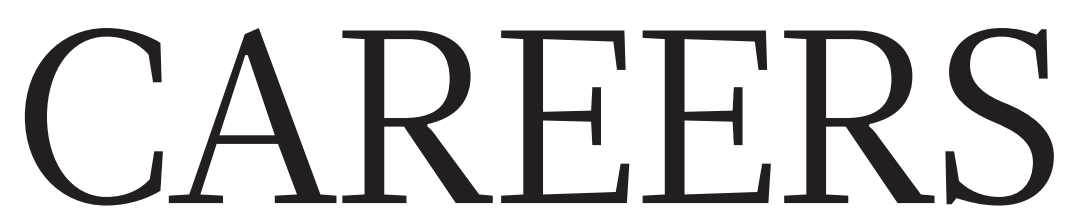

EDUCATION Study probes how US graduate training can meet employers' needs $\mathbf{p . 6 2 3}$
FINANCES Report says money pressures are still squeezing US universities $\mathbf{p . 6 2 3}$
NATUREJOBS For the latest career listings and advice www.naturejobs.com

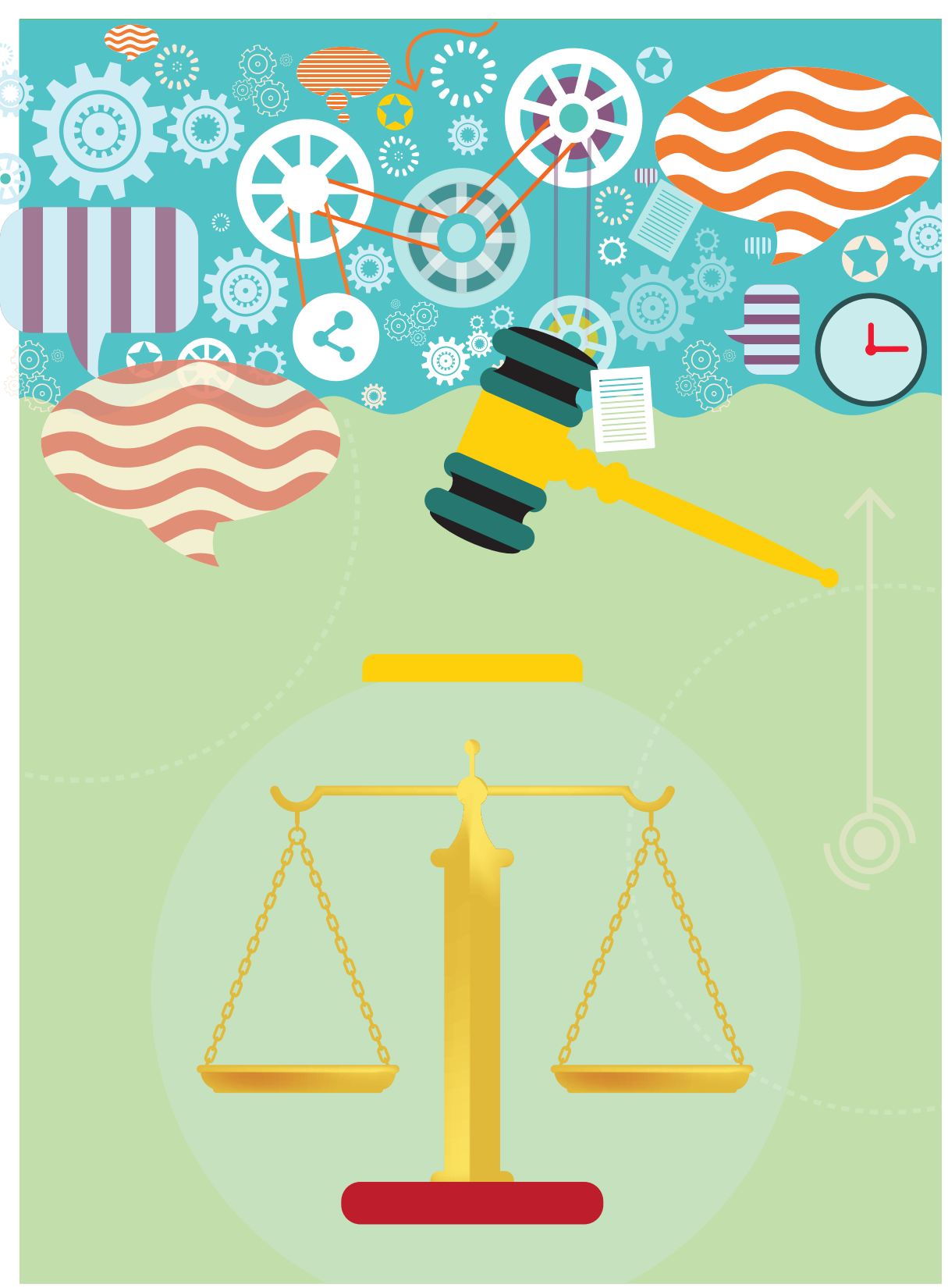

PATENT LAW

Finding a balance

Scientists who decide to pursue a legal career can enjoy fresh challenges while staying connected to the research world.

BY CAMERON WALKER
A fter Jason Rutt filled out a careerassessment survey as a teenager, he was given three job options: soldier, farmer or patent attorney. At the time, says Rutt, all he knew about patents was that the Nobel-prizewinning physicist Albert Einstein had worked in a patent office. It was not until years later, while pursuing a $\mathrm{PhD}$ in synthetic organic chemistry at the University of Nottingham, UK, that Rutt thought about patents again.

He spent six months of his $\mathrm{PhD}$ in the Nottingham laboratories of Boots, the international pharmacy and health-and-beauty chain. While there, he learned about the company's other departments, including the patent division, where attorneys secured patents for inventions and protected existing intellectual property from challenges. Rutt later returned to Boots to do research, but by then his desire to continue in research and development was waning. He decided to change tack: as a patent attorney, he realized, he would not only help clients to secure and protect intellectual property, but would also be able to work closely with researchers in many fields of science.

\section{EASY SWITCH}

The transition to law was fairly simple for Rutt, because he did not need a law degree, just on-the-job training and professional qualifications. By coincidence, a trainee position opened up in the patent department at Boots at the same time that Rutt decided he was interested in the field. He got the job. Now, as head of patents in the London office of the international intellectual-property firm Rouse, he works with pharmaceutical companies and start-up ventures in areas such as gene therapy and diagnostics.

Scientists move away from hands-on research and into the legal field for a variety of reasons. Some have a long-standing interest in law and policy; others believe that a career in law will allow them to be stronger advocates for research than they could be as scientists. Some consider a career in patent law because it dovetails with many scientific fields and will enable them to remain close to the research world. Patent attorneys may work directly with researchers to learn more about a client's techniques and inventions they often hear about the latest ideas long before the research is published.

A patent attorney is not the only option for scientists who want to enter the legal field. 
- Researchers with health or epidemiology backgrounds may choose to work as a legal counsel for public-health or regulatory agencies as the organizations apply for medicalresearch funding or examine bioethical issues. Graduates in environmental science or ecology may find positions helping government agencies to develop energy regulations or petitioning for endangered status for various species on behalf of environmental non-profit organizations (see 'From the lab to the law').

While studying the ecology of artificial reefs as part of a master's degree in environmental management, Margaret Peloso took classes in environmental law. That made her realize that she wanted to use her scientific background to develop policy, and she went on to pursue a $\mathrm{PhD}$ that combined science and policy while getting her law degree. She now focuses on environmental law and climate change in the Washington DC office of Vinson \& Elkins, an international law firm specializing in energy and finance. Her work involves developing the firm's climate-change practice - she researches legal aspects of climate change and educates clients about potential risks and benefits, which fits in with her PhD on legal and policy issues surrounding sea-level rise.

\section{WORLD CLASS}

Qualifying as a legal professional varies from country to country. In the United Kingdom, prospective lawyers usually take an undergraduate degree in law. People who already have a degree - including one in science can take a one-year postgraduate diploma in law. In both cases, extra coursework and training is required before being able to practise as a barrister or solicitor. But a law degree is not required for people with science and engineering backgrounds who want to become patent attorneys or to bring inventions to the European Patent Office (EPO). Instead, they do several years of onthe-job training, then sit national or EPO examinations.

In the United States, most of those wishing to become a practising attorney must gain an undergraduate degree and a law degree. After receiving their juris doctor (JD), they must then pass a state bar exam. (In a handful of states, it is possible to qualify to take the state bar exam after completing a lengthy legal apprenticeship.)

Yet the United States still has entry routes that do not require a law degree. Law firms often hire people with strong science backgrounds as technical specialists to help the firm to prepare patent applications for its technologies. These 'tech specs' often work directly with researchers and inventors to learn about their work, examine the scientific literature to find out whether similar techniques or ideas have already

\section{FROM THE LAB TO THE LAW}

\section{A science background opens doors in the legal world}

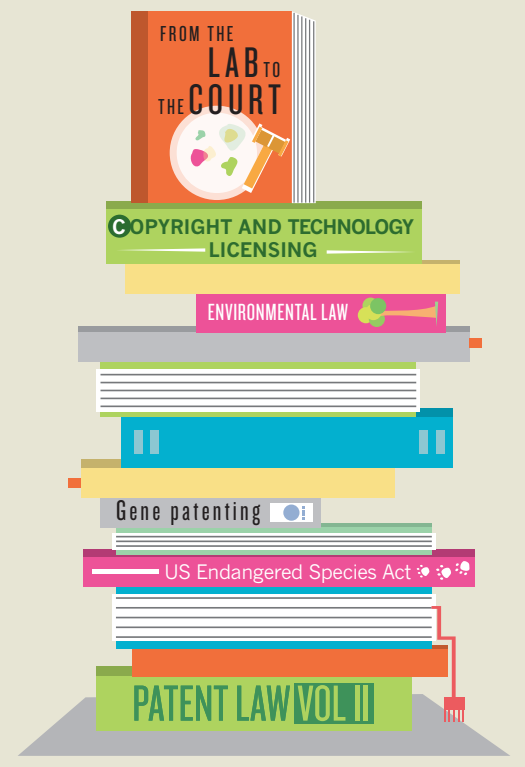

Shifting from a science-focused track to a legal career can be a bit bumpy, from the challenges of learning the language of law to studying for examinations. But it will be smoother for those who have a clear view of their target. Attorney Collette Adkins Giese in Minneapolis, Minnesota, had initially wanted to make an impact in the conservation world through research and teaching. After earning a master's degree in wildlife conservation and lecturing for several years, Giese realized that she wanted to be an advocate for environmental research.

So she returned to the University of Minnesota's Twin Cities campus for a joint juris doctor law degree and $\mathrm{PhD}$ programme in conservation biology. She spent her summer holidays as an intern at Earthjustice, an environmentallaw organization, and for non-profit conservation groups, including Defenders of Wildlife in Washington DC. There, Giese made valuable connections and established her commitment to the legal and nonprofit sectors - a double benefit because, she says, non-profits are often reluctant to hire newly minted lawyers. Law-school graduates do not always leave school with practical skills and could need on-the-job training, for which non-profit organizations may not have resources.

But after earning her law degree in 2005 , she clerked for a judge who presided over criminal and contract issues, as well as some environmental law. She honed her writing skills by drafting the judge's orders and opinions. Then she spent several years at a large corporate law firm in Minneapolis that had an established training programme for associates. With the firm, she worked on behalf of the plaintiffs in the 1989 Exxon Valdez oil spill and represented environmental non-profit organizations through the firm's pro bono programme. In her current role as a senior attorney for the Center for Biological Diversity in Tucson, Arizona, she focuses on protecting reptiles and amphibians.

For Giese, working as an attorney is the best way for her to use her scientific knowledge. "I really love the law, and I see how it changes and can make an impact. Important things get decided in courts," she says, "and I just want to be a part of that."

Another scientist-turned-lawyer is Heriberto Moreno. Moreno became interested in intellectual property as an undergraduate student at the University of Puerto Rico, where he had taken an elective class in technology transfer.

The class had given him the idea of training as a patent attorney. Towards the end of his microbiology $\mathrm{PhD}$ at the University of Virginia in Charlottesville, he perused the university's alumni database to find scientists-turned-patent attorneys and contacted them to learn more about their jobs. He also visited the school's career centre and looked online to find law firms that offer programmes and positions for technical specialists.

One that captured his interest was an intellectual-property firm based in Washington DC. Moreno contacted the head of the firm's biotechnology division and ended up working there as a technical specialist on patents in areas including nutraceuticals - products such as dietary and herbal supplements pharmaceuticals and green technology. Over time, he took on more responsibility in drafting patent applications and realized that the next logical step was to become an attorney.

Moreno is now in his final year at Boston University's School of Law in Massachusetts. He also works as a technical specialist in areas including pharmaceuticals and biologics at the Boston office of the law firm McCarter \& English. He has had to adapt to being older than most of his fellow students and managing the challenges of full-time study. But his mindset is different now that he has had a taste of his future career as a patent attorney. One of the best parts of patent law, he says, is its variety. "You just never know what you'll be working on." c.w. 
been published and determine whether an innovation overlaps with technologies that have already been patented. Researchers who pass the US Patent and Trademark Office registration exam can then develop and file patent applications - although they cannot advise clients on legal issues or go to court if a patent is infringed.

If a scientist earns a JD and passes both patent and state bar exams, she or he can work in patent law and develop a fullservice intellectual-property practice, which may involve working with clients on trademarks, copyrights and technology licensing. Scientist-attorneys can also help clients, particularly start-up firms, with issues such as entity formation, employment agreements and general legal services, and can practise in other fields of law as well. In some cases, employers will reimburse tuition fees or provide other forms of support to tech specs or patent agents who attend law school while working.

\section{BACK TO SCHOOL}

The idea of returning to higher education can be daunting for an early-career researcher, says Dianne Nicol, a law professor and deputy director of the Centre for Law and Genetics at the University of Tasmania in Hobart, Australia. But, she says, the extra training can help to develop one's career.

After earning a $\mathrm{PhD}$ in cell biology from Dalhousie University in Halifax, Canada, and a law degree in Tasmania, Nicol spent several years in a private legal practice, working on intellectual property as well as on contract work and personal-injury litigation. She now researches and writes about issues such as gene patenting, the privacy of genetic information, regulations underlying biobanking and direct-toconsumer genetic testing. Her research has been used to inform government reports on genetic privacy and health issues surrounding genetic patenting, and she was recently appointed to a three-member panel that reviews pharmaceutical patents. Nicol relies heavily on both her science background - from the fundamentals of genetics she learned as an undergraduate to her postgraduate training - and her legal education. "Even though it sounds like a long and laborious process, it's worthwhile," she says.

The lingering effects of the global recession have meant that job prospects for fledgling US lawyers is gloomy: the American Bar Association announced this year that just $57 \%$ of the 46,776 people who received a JD in 2013 - the largest number of new JDs ever - had found long-term, full-time jobs in law that had required them to pass the bar examination. But the news is not all bad. People with science

backgrounds may have an edge on their peers, both in terms of law-school admission and in finding gainful employment after graduating, says Joy Baker Peacock, assistant director of the High Tech Law Institute at Santa Clara University School of Law in California. Many law schools and institutes are keen on training students who have physics, engineering and computer-science backgrounds - once qualified, such candidates may be appealing to employers in areas including semiconductors, photovoltaics and nanotechnology.

Peacock says that attorneys with a PhD in the life sciences are valuable in the biotechnology patent-prosecution field because they will have the necessary knowledge to work with clients and the officials on protecting intellectual property. Although litigators - attorneys who usually work for plaintiffs and defendants in patentinfringement cases - do not require a science background, she says, it can be an advantage. "Firms like to hire people that have a strong grounding in technical and scientific matters so that they will be able to get up to speed more quickly on the tech-

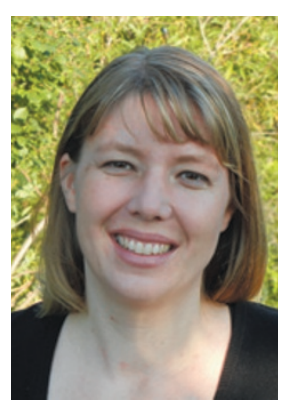

"I really love the law. Important things get decided in courts. Ijust want to be a part of that." Collette Adkins Giese nical aspects of patent-infringement cases."

Combining science and law can be a way to channel a passion for science into realworld impact and personal satisfaction. "I know scientists strive to be unbiased," says scientist-turnedattorney Collette Adkins Giese. Now it is her job to make the case for protecting rare animals and species for the non-profit Center for Biological Diversity, based

in Tucson, Arizona. In 2012, Giese filed the largest-ever petition involving reptiles and amphibians to the US Fish and Wildlife Service to protect 53 species under the US Endangered Species Act. It was a 450-page document that involved nearly a year of preparation, including literature reviews and discussions with experts.

As a lawyer, she is now free to be an advocate for her interests. "You can't hide behind the notion that you're just presenting the facts anymore," she says. "For me, that was such a relief."

Cameron Walker is a freelance writer in Santa Barbara, California.

\section{EDUCATION}

\section{Graduate skills survey}

The Council of Graduate Schools in Washington DC is examining the professional-development requirements of $\mathrm{PhD}$ and master's students in science, technology, engineering and mathematics (STEM) programmes. The council will survey 500 member institutions and interview industry leaders to determine which skills are most important for STEM graduates and which remain unaddressed in US graduate programmes. Daniel Denecke, the council's associate vicepresident for programmes, says that the study, which is funded by a US $\$ 298,100$ grant from the National Science Foundation, is focusing on industrial employers because they are the most likely to hire STEM graduates. Results will be available by summer 2016 .

\section{FUNDING}

\section{Marion Mason award}

A US\$2.2-million bequest from the estate of a venerated US chemist will support early-career female chemists over the next 20 years. Recipients of the Marion Milligan Mason Award for Women in the Chemical Sciences will receive $\$ 50,000$, which may be used for laboratory supplies and equipment; publication costs; computer and technical support; and attendance at meetings. Applicants must have a tenuretrack post at a US $\mathrm{PhD}$-granting institution and must be US-born, naturalized citizens or permanent residents. The awards are administered by the American Association for the Advancement of Science in Washington DC. Applications are due by 15 September, and winners will be announced by May 2015.

\section{FINANCIAL OUTLOOK \\ Continued squeezes}

US universities are likely to face continued financial pressures over the next $12-18$ months, says a report by Moody's Investors Service in New York. Negative Outlook for US Higher Education Continues Even as Green Shoots of Stability Emerge predicts that competition for tuition revenue, federal grants and state funding will affect regional public universities most; prominent private universities with large endowments will perform well. The negative outlook means that Moody's is more likely to give US universities poor credit ratings; as a result, they will incur higher borrowing costs and may have to cut back on hiring. 